
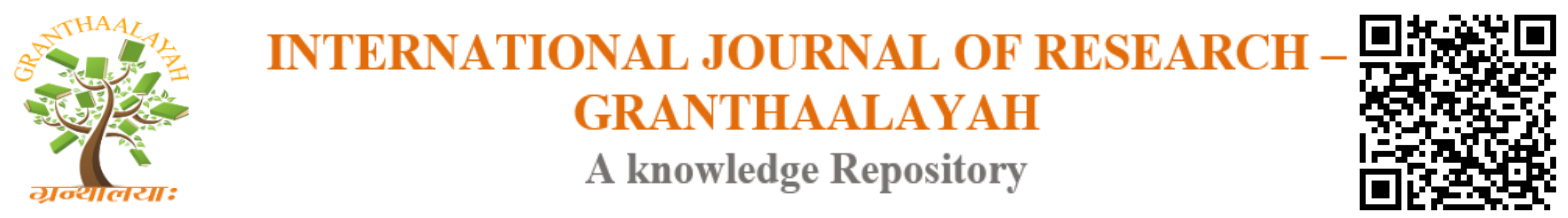

Social

\title{
DEVELOPMENT OF STATIC FLUID LEARNING PROPS TO IMPROVE STUDENTS' ARGUMENTATION SKILLS
}

\author{
Muhammad Iwan ${ }^{1}$, Agus Suyatna *2, Warsito $^{3}$ \\ ${ }^{1}$ State Vocational High School 2, Bandar Lampung, Indonesia \\ 2 Physics Education Graduate Program, Lampung University, Indonesia \\ ${ }^{3}$ Physics Department, Lampung University, Indonesia
}

\begin{abstract}
This study aims to develop static fluid material props in an effort to improve students' argumentation skills. Design development using 4-D development model consists of four stages, namely Define, Design, Development, and Disseminate. The test subjects of this study were 5 physics teachers and 75 students from three high schools in Bandar Lampung. Data were collected through observation in the preliminary study, questionnaires to see the responses of students, teachers, and experts on the developed aids and tests of the method of one pretest and posttest design. The questionnaire data were analyzed using scoring techniques and improved learning outcomes using the $\mathrm{N}$-gain formula. According to the response of students and teachers there is a clear U-shaped hose that contains water that can be observed movement, there are sensors and LED lights that can live when the movement of water through the sensor. The second props are simple hydraulics to prove Pascal's law by laying loads of different weight on both sides of the piston with different cross-sectional areas. An effective tool for improving student learning outcomes and argument skills involves making claims and warrants, effective enough to improve the skills of backing, but less effectively to improve rendering skills.
\end{abstract}

Keywords: Props; Guided Inquiry; Argumentation Skills.

Cite This Article: Muhammad Iwan, Agus Suyatna, and Warsito. (2018). "DEVELOPMENT OF STATIC FLUID LEARNING PROPS TO IMPROVE STUDENTS' ARGUMENTATION SKILLS.” International Journal of Research - Granthaalayah, 6(6), 296-309. https://doi.org/10.29121/granthaalayah.v6.i6.2018.1374.

\section{Introduction}

Lessons learned at school both in the classroom and in the laboratory from elementary, junior and senior high schools are generally mutual activities between teachers and students. The process of reciprocity is a series of teaching and learning activities where students are more dominant than teachers. The goal is that more students get the opportunity to observe, ask, experiment, collect and process data, and present it in front of teachers and friends in accordance with the scientific approach. Teaching is an effort to organize the environment so as to create learning conditions for 
students [1]. Climate learning as this is what will shape the character and character of students become more independent, confident, tenacious, responsible, tolerant, and able to communicate scientifically. Conventional learning in schools and teacher paradigms still regard themselves as teacher centered and students as loyal listeners are still ongoing. As a result the learning situation becomes not conducive, and students become saturated. Physics is a part of natural science that consists of concepts that require proof through experimentation both in demonstration and students who directly implement it.

Experiments of the concept of static fluid require props as a way to eliminate abstractions so that students can understand physics concepts properly and correctly. The use of props can assist in science learning so that the delivery of concepts becomes more meaningful [2]. Furthermore, according to [3] that learning by using visual aids is a series of activities to deliver lesson material that aims to give learners opportunities to actively learn to enable learners to gain knowledge and develop psychomotor skills and foster creativity of learners to solve problems faced. Existing research includes research conducted by [4] on the development of static fluid props. The use of teaching aids in learning should be guided by the teacher. The lesson that is applied is guided inquiry. Guided inquiry learning enables learners to build knowledge independently and helps learners to develop an understanding of concepts and develop scientific steps [5]. All inquiry activities involve process skills that include basic process skills, measurement and calculation skills, experimental planning skills, and the skills of processing and presenting data [6]. According to [7] Guided inquiry provides opportunities for thinking for students and also provides opportunities for other students to develop scientific methods and students' scientific attitudes. In addition, students must report their findings both verbally and in writing. The visual aids used in inquiry learning will grow and familiarize students with being scientific and building argumentative abilities.

Here are the skills that will appear in the inquiry according to [8]: 1) presented a phenomenon, 2) made the research question, 3) wrote the hypothesis, 4) planned the experiment to test the hypothesis, 5) after obtaining the data, analyzing and interpreting the results, 6) draw conclusions, 7) express opinions. The conditioned learning is like the above steps, as stated by [9] that the application of inquiry learning model is effectively guided to improve the mastery of concepts and performance. One of the goals of science education is to provide students with the ability to formulate arguments and criticism in scientific contexts, formulate arguments in developing and conducting scientific activities. Conducting inquiry experiments has the potential to build evidence-based arguments, unlike in other studies showing that students find it difficult to adopt evidence-based arguments. Arguments in a scientific context must be an integral part of this process. Working in small groups, where members are exposed to scientific duty, gives them the opportunity to engage in debates and must be supported or rejected by their arguments. During group debates, sometimes with teacher intervention, groups have the opportunity to build individuals as well as group knowledge.

Based on preliminary research that has been done in 2 State Senior High School in Bandar Lampung obtained data $95 \%$ of students expect props that attract attention to conduct experiments, $88 \%$ of students expect props developed in accordance with inquiry steps, and $83 \%$ of students expect props developed to train students to express their opinions (argumentative ability). Whereas from the teachers, it is found that $100 \%$ of teachers want visual aids designed and made by students 
to develop their argument ability, 100\% of teachers want teaching aids that guide students to find concepts and help display skills in conveying opinions based on experimental results, and 100\% of teachers will using the product of the development result. Based on the above description to achieve a more conducive learning climate, fun for learners, and reduce student abstraction on static fluid concept need to manifested static fluid matter props with guided inquiry approach so that students' argumentation ability increases.

\section{Materials and Methods}

\subsection{Research Design}

The development model in this study used 4-D adapted by [10]. The 4-D model consists of four stages: Define consisting of preliminary study, needs analysis, literature study, and objective formulation, Design consisting of media determination, and making media design, develop consisting of initial product (prototype), expert test media, expert material tests, limited trials, expert test revisions (prototype 2), revisions (prototype 3), field tests, media revisions, end products and Disseminate. Data of attractiveness, practicality, and benefit to students, teachers, and validators are obtained from questionnaires. While the effectiveness of learning with visual aids obtained from student learning using multiple choice questions.

\subsection{Research Sample}

Sampling technique in this research use purposive sampling. The sample in this study were 75 students and 5 physics teachers from three high schools of two public high schools and one private high school.

\subsection{Research Instruments}

Instruments in this study using questionnaires and physical problems. Questionnaire contains items of attractiveness, practicality, and expediency. Questionnaires are given to students, teachers, and expert validators. While the problems of physics are given to students both pretest and posttest to measure the effectiveness of physics learning outcomes.

\subsection{Data Analysis}

The data analysis of attractiveness, practicality, and the benefit of props of development result are obtained from questionnaire given to students, teachers, and validator (expert lecturer). Data were analyzed and interpreted according to [11] as listed in table 1 below

Table 1: Assessment Score Scores Being a Quality Value Statement

\begin{tabular}{|l|l|}
\hline Score (Percentage) & Criteria \\
\hline $\mathbf{8 0 , 1 \%}-\mathbf{1 0 0 \%}$ & Very high \\
\hline $\mathbf{6 0 , 1 \%}-\mathbf{8 0 \%}$ & High \\
\hline $\mathbf{4 0 , 1 \%}-\mathbf{6 0 \%}$ & Medium \\
\hline $\mathbf{2 0 , 1 \%}-\mathbf{4 0 \%}$ & Low \\
\hline $\mathbf{0 , 0 \%}-\mathbf{2 0 \%}$ & Very low \\
\hline
\end{tabular}


Data on the results of physics learning or the effectiveness of the use of visual aids in learning were analyzed using the $\mathrm{N}$-gain formula [12] which can be seen in table 2 below

\section{Table 2: Normalized Gain Criteria}

\begin{tabular}{|l|l|}
\hline N-Gain Score & Normalized Gain Criteria \\
\hline $\mathbf{0 , 7 0}<\mathbf{N}-$ Gain & Very effective \\
\hline $\mathbf{0 , 3 0} \leq \mathbf{N}-$ Gain $\leq \mathbf{0 , 7 0}$ & Effective \\
\hline N-Gain $<\mathbf{0 , 3 0}$ & Less effective \\
\hline
\end{tabular}

\section{Results and Discussions}

The product development results are manifested in the form of integrated props applying a guided inquiry learning model to improve argumentation skills on static fluid materials. The first tool in table 1 measuring $20 \mathrm{~cm}$ x $25 \mathrm{~cm}$ serves to measure hydrostatic fluid pressure in a container with a depth of five twelve centimeters. When the tip of the hose is immersed at a depth of three centimeters into the fluid then the fluid at the other end of the hose that has been equipped with the line level sensor will read the fluid rising as high as one centimeter. The sensor connected to the indicator light automatically reads the rising fluid movement and the indicator light becomes alive indicating that there is a pressure inside the fluid of three hundred Pascal. The accuracy of the props can only be measured at a depth of fifteen centimeters with a maximum increase of fivecentimeter fluid. The display tool in the second table measuring $15 \mathrm{~cm} \mathrm{x} 15 \mathrm{~cm}$ x $20 \mathrm{~cm}$ is to prove Pascal's legal application of props has two pistons with an area different, the area of piston 2 by two times the area of piston 1 and the weight of the load 2 by two times the weight of the load 1. The difference in cross-sectional area of both pistons because the load is above each piston is also different, because the piston area 2 twice the area of piston 1 then piston 1 is loaded with two hundred newton so that a balanced system over piston 2 is laid by a load of four hundred newton four loads are provided for the truth of the Pascal legal application to be properly realized. The accuracy of the props is quite good because the leakage rate of the fluid is very low, the fluid is in an iron pipe and the piston is equipped with rubber that is very chewy and slippery when rubbing against the wall of the pipe because it is given oil. The two development props are shown in Table 3 below 
Table 3: Results of Upgrade after Display Validation

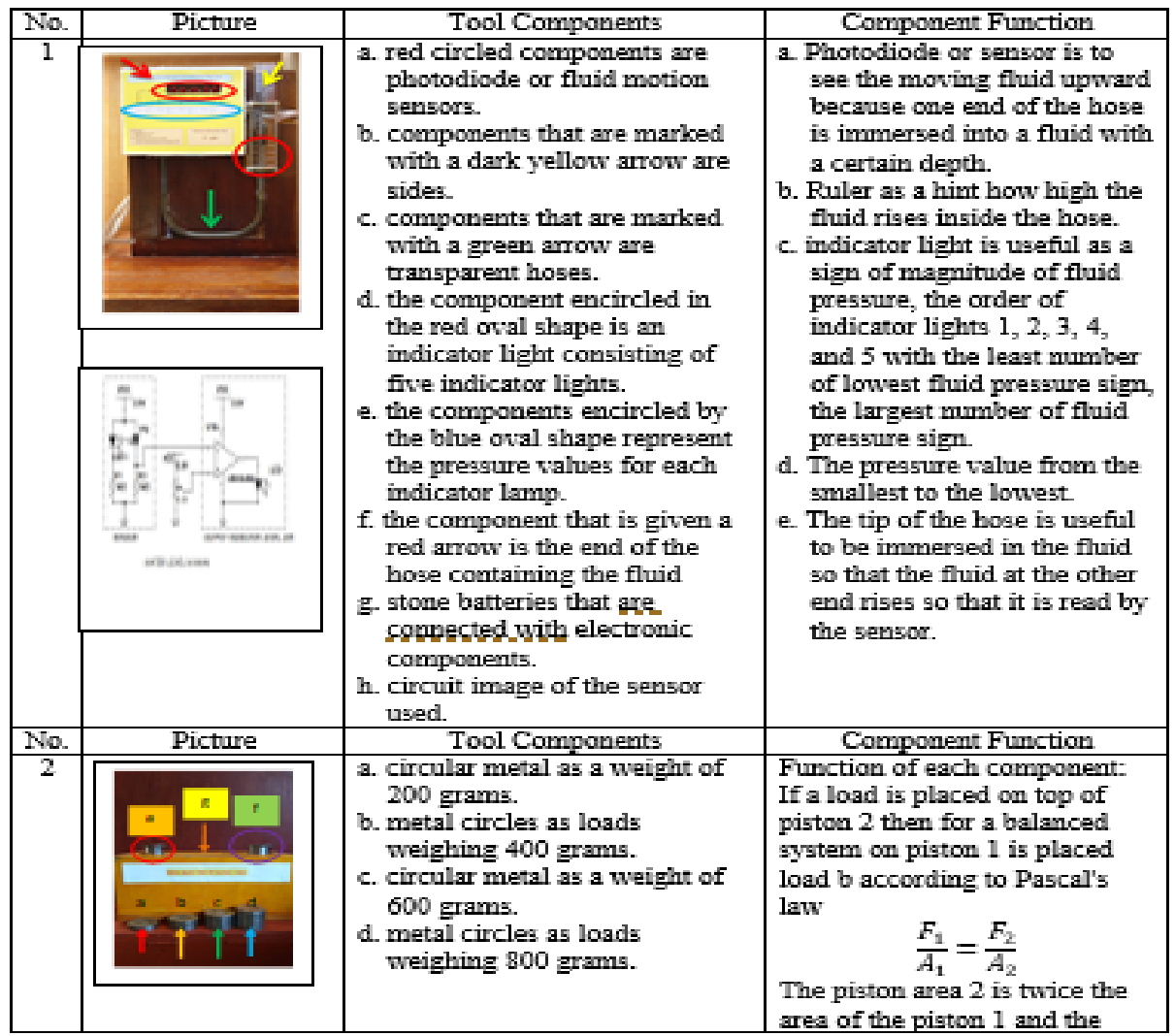

Design expert validation aims to assess the attractiveness test that has five aspects: the form of exciting props, the ease of finding the tool in the box, the ease of taking, storing in the box, and easy to carry, made of materials that can be relatively long or repetitive, and easy to maintain every tool component. The Test of Interest earned an average score of 3.4 or when converted in percentage of $85.0 \%$ which means very high. Practical test consists of five aspects that become indicators of assessment, the average score obtained by 3.4 or when converted in percentage of $91.67 \%$ which means very high. Benefit test consists of three aspects that become indicators of assessment, the average score obtained by 3.4 or when converted in percentage of $87.5 \%$ which means very high. If reviewed as a whole, then the product feasibility of the aspect of attractiveness, practicality, and the benefits of the product obtained a percentage average score of $88.06 \%$ which means the product has a very high quality, and feasible to use in learning. Recapitulation of proprietary tools by the design validator presented in figure 1 .

\section{Recapitulation of Expert Validation Results}

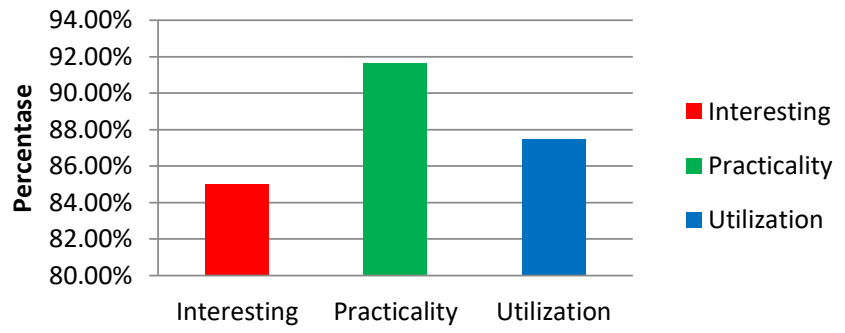

Figure 1: Experiment Validation Diagram 
Individual test aims to test the legibility of products based on components of attractiveness, practicality and usefulness to the product of development. The test subject is 6 high school students in Bandar Lampung City. Three components used to test the legibility of attractiveness, practicality and usefulness. The attractiveness test has four aspects assessed, for the aspect of attractiveness earning $83 \%$ which means very high. Practicality test has five aspects assessed, for the practical aspect of getting a 90\% value which means very high. The benefit test has six aspects that are assessed, for the benefit aspect to get $89 \%$ which means very high. The diagram of the test of attractiveness, practicality, and overall benefit can be seen in Figure 2 .

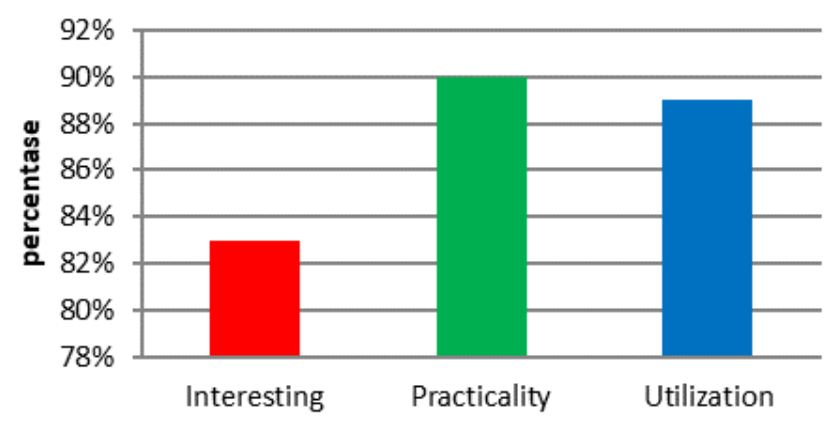

Figure 2: Diagram of Individual Test Results According to Student

After going through the individual test phase, the next step is to test the product to 5 high school physics teachers from three high schools in Bandar Lampung. Trial use of the product is done by filling the questionnaire of attractiveness, practicality, and expediency. The attractiveness test consists of three aspects that become an assessment indicator, the average score obtained is 3.2 or equal to $80.0 \%$ which means high or interesting. The practicality / convenience test given to the teacher consists of eight aspects that become an assessment indicator, the average score obtained is 3.2 or equal to $80.6 \%$ which means very high or very easy. Meanwhile, for the benefit test consists of three aspects that become indicators of the assessment, the average score obtained for the benefit test of 3.4 or equal to $85.0 \%$ which means very high or very useful. The diagram of the test of attractiveness, convenience, and overall benefit can be seen in Figure 3.

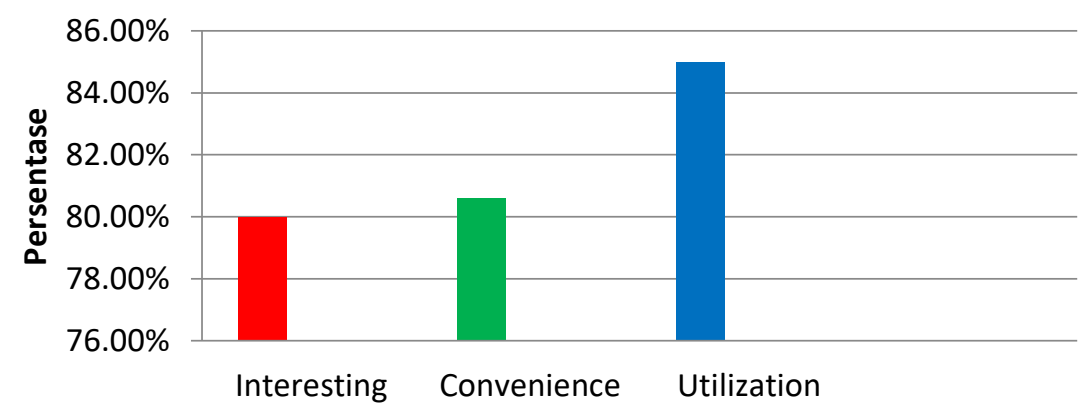

Figure 3: The Test Chart of Attraction, Convenience, and Product Utilization According to Master

Then the students are given learning using props which have been developed (prototype III), but previously done pretest to know the initial ability of student argumentation. After doing the pretest, then do the learning activities by applying props that have been developed. At the beginning of the meeting, students are introduced with the argumentation skills that must be displayed through 
written statement on props, then conducted learning activities. The learning process begins with instructions to all students to form groups of five groups with five groups each. Representatives of each group are given props to carry out practicum activities. The first demonstration tool provided is a hydrostatic pressure gauge. Before the learning begins the teacher explains the learning objectives to be achieved by the students, the function, completeness, dimensions, accuracy and parts of the props.

The first learning objective is to prove the presence of pressure in the fluid. Each group begins practicum activity using props, students in each group have their own assignments. The first step of using props is that one end of the hose is immersed in a fluid with a maximum depth of $3 \mathrm{~cm}$ automatically the fluid at the other end rises as high as $1 \mathrm{~cm}$. This increase is read by the sensor so that the first indicator light is on and shows a pressure of $300 \mathrm{~Pa}$. Second, the hose is immersed in fluid at a depth of $6 \mathrm{~cm}$ and the fluid at the other end rises $2 \mathrm{~cm}$ so that the second indicator of life indicates a pressure of $600 \mathrm{~Pa}$. Third, the end of the hose is immersed at a depth of $9 \mathrm{~cm}$ then the fluid at the other end rises $3 \mathrm{~cm}$ so that the live indicator light shows a pressure of $900 \mathrm{~Pa}$. The four ends of the hose are immersed into a fluid at a depth of $12 \mathrm{~cm}$ then the fluid at the other end rises $4 \mathrm{~cm}$ and the live indicator light shows a pressure of $1200 \mathrm{~Pa}$. Fifth, the end of the hose is immersed in a fluid with a depth of $15 \mathrm{~cm}$ then the fluid at the other end rises as high as $5 \mathrm{~cm}$ and the live indicator light shows a pressure of $1500 \mathrm{~Pa}$. At this stage data and claims have been established and the data obtained from the experimental results is used to make a statement (warrant). The next step students create support (backing) of the existing warrant. Finally the teacher conditioned the class in order to engage the debate between groups (rebuttal).

Conducting data analysis, students begin to seek information support related to the findings obtained. Students link data with existing theory. Students analyze data guided through questions that have been presented in the matter. At the time of drawing conclusions, students connect theory with data obtained through experiment, by providing various support. Furthermore, there is one representative group who presented the results of the experiments that have been done. At the time of presentation the students provide arguments in the form of claim, warrant, backing, and rebuttal. In order for students to be able to provide a rebuttal statement, the teacher is conditioned to make a debate about the results of the experiments obtained. After completion of the presentation, the teacher provides reinforcement about the pros and cons of the student's findings. Next step, the student performs the posttest.

There appears to be an increase in the average learning outcomes after applied learning using props. Increased student learning outcomes based on pretest and posttest averages are presented in figure 4 below.

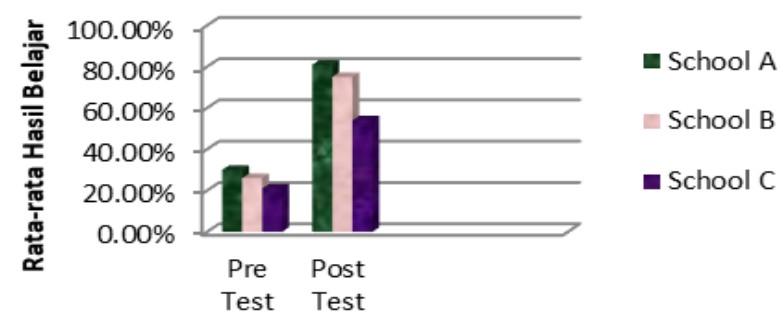

Figure 4: Graph of Increased Student Learning Results 
After obtaining initial and final test results, then analyzed the effectiveness of products that have been developed by comparing students' argumentation skills before learning is done with after learning using props. The level of product effectiveness is obtained based on the average $\mathrm{N}$-gain value, to see an improvement in concept comprehension calculated using the N-gain formula [12]. Analysis based on the average value of $\mathrm{N}$-gain, the results obtained that the application of props in School A, and School B effective, while in School C is effective enough to improve the results of physics learning on static fluid material. The effectiveness of props can be seen in Figure 5. The following recapitulation of product effectiveness data by categorizing the gain value of each school. The average $\mathrm{N}$-gain graph is shown in Figure 5.

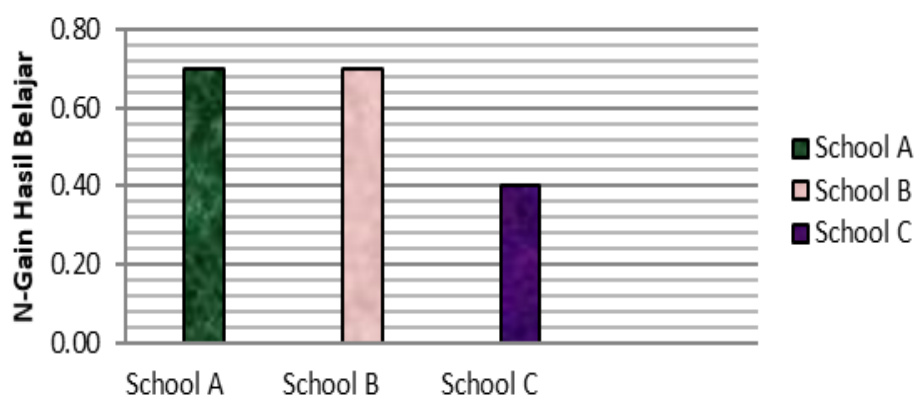

Figure 5: Graphic of N-Gain Learning Outcomes

The results of the development of the form of props suitable for applying guided inquiry stages, can improve learning outcomes, and impact on improving students' argumentation skills. The argumentation skills indicators assessed are claim, warrant, backing, and rebuttal. The average percentage obtained by students when answer about claim reach $73.3 \%$ which means high. The average percentage gained when completing the warrant problem is $80.0 \%$ which means very high. The average percentage gained when completing the backing problem is $28.0 \%$ which means low. While the average percentage obtained when solving the problem rebuttal of $25.3 \%$ which means low. This is stated in Figure 6 below

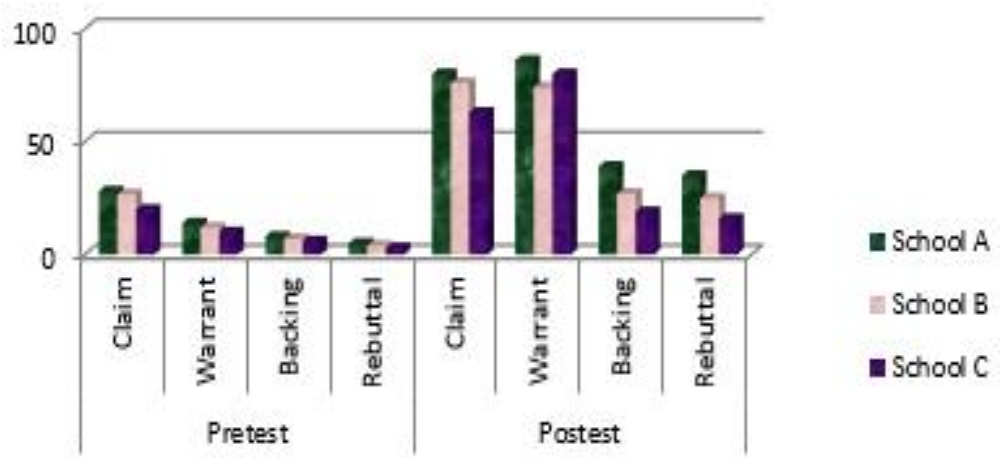

Figure 6: Recapitulation of Percentage of Argumentation Skills

Meanwhile, for the mean value analysis of N-gain students' argumentation skills for each indicator is summarized in figure 7 below: 


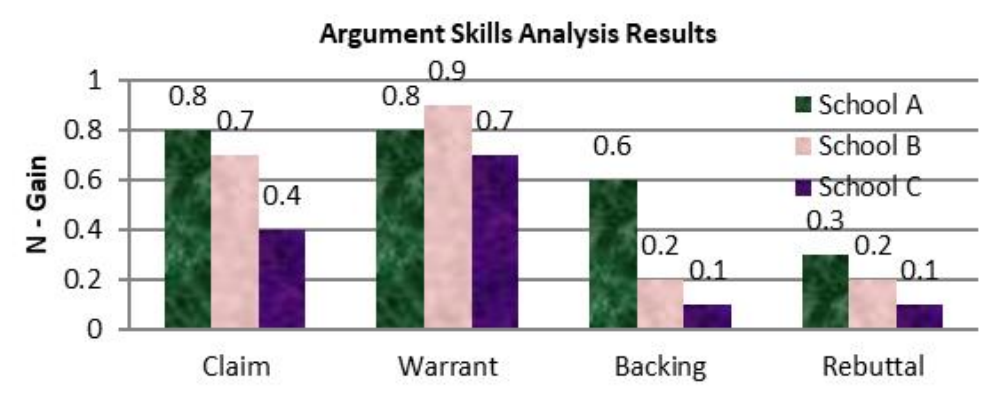

Figure 7: Average N-Gain Argumentation Skill

At each inquiry stage students are guided to display various indicators of argumentation skills. The researcher uses the argumentation component according to [13] which consists of claim, warrant, backing, and rebuttal. At each stage of guided inquiry, students are assisted

The results of the attractiveness of the props test obtained a high rating which means interesting. Indicators of attractiveness appraisal The attractiveness test has five aspects assessed: the form of props (KIT) interesting, the ease of finding the tool in the box, the ease of taking, storing in the box, and easy to carry, made of materials that can be relatively long or repetitive, and easy to take care of every tool component. The attractiveness of the props used to prove the pressure on the water using a sensor flanking the transparent hose when one end of the hose is immersed into a container containing water then the water in a hose flanked by the sensor rises automatically at regular intervals, if the tip of the hose is dipped into in water with a depth of $3 \mathrm{~cm}$ then the water in the hose is flanked by the sensor will rise as high as $1 \mathrm{~cm}$ and read by the sensor so that the first lamp as an indicator will live so on. Test of practicality consists of five aspects that become indicators of assessment with very high results means the props used quite practical in this case the students directly use the tool to experiment. Benefits test obtained an assessment of $87.5 \%$ which means very useful, because the first, props provide opportunities to implement learning in concrete or eliminate abstraction using guided inquiry model. Because during this teacher difficulty in eliminating the abstraction of theoretical physics and realize the theory in the form of a practicum.

Based on the above exposure it can be said that the visual aids make it easy for the teacher to carry out the learning. This is in accordance with the statement [14] props is a vehicle for channeling messages or learning information. Teachers need an object or a tool to explain a concept so that students more easily understand the material presented by the teacher so that students are given the opportunity to find concepts, build their own knowledge and play an active role in the learning process. In general the props interesting, very practical, and very useful in learning activities. This is in line with the response given by students that the average response given by students is $83 \%$, which means that students respond positively with high criteria to the props that has been developed. The following are the positive responses given by the students.

First, the teaching aids provide high motivation to the students to follow the learning. This appears when the learning activities take place enthusiastically students follow well from observing the phenomenon, giving hypothesis, experimenting, analyzing data, drawing conclusions, to present the results of experiments. The visual aids give students the opportunity to conduct scientific activities so that students dominate the learning process. This is in line with the assertion [15] that 
props as a component type in the student environment can stimulate them to learn including the tools used in the learning process, and [16] that by applying inquiry-based learning, the teacher will act as facilitator, student become more active.

Second, props train students to argue at each stage of learning. The response given is $62 \%$, which means that the positive response is given with high category. Students practice to provide statements based on data, facts, and supported by the underlying theory, and able to provide a rebuttal if the results are not in accordance with the findings based on experimental results. This means students have started to get used to argue/statement based on data and theory. When it comes to presenting students' experimental results so enthusiastically, and when answering questions from other groups, students are able to convince other groups based on data obtained through experiments and linked to existing theories/principles. It's just that, when students present the results, teachers do not provide stimulus to each group to defend their argument, so that the debate becomes less than the maximum. This is consistent with the assertion [17] that teachers should provide stimulus to individual students' groups to defend their arguments so that the atmosphere of debate becomes optimal.

Third, students' responses to innovation in learning activities get a percentage of $75 \%$ which means high. Students feel the first time to use props that apply guided inquiry activities to display argumentation skills. Students are also the first to understand the argumentation skill indicators. When students provide a statement/argument, then the students are required to provide evidence in the form of data/facts, or theory underlying, based on experimental results or based on the results of literature review.

Fourth, the student's response to the desire to use the tool inquiry learning is guided to empower students' argumentation skills on other physics material is very high. Positive response of students reaches $84 \%$ which means very high.

The product effectiveness test was conducted by conducting field test using One Group PretestPosttest Design method, the average pretest value of 25 students in School A was 29.6 after being given treatment in learning using posttest value props to 80,9 with $\mathrm{N}$ value -gain 0.7 which means effective. The average pretest score of 25 students in School B is 25.7 and then given learning using props and then given posttest obtained an average value of 75.3 with a value of $\mathrm{N}$-gain 0.7 which means effective. The average value of pretest 25 students of School $\mathrm{C}$ is 21.0 then given learning using props then given posttest get an average value of 54.3 with a value of $\mathrm{N}$-gain 0.4 which means quite effective. If the averaged 75 students' pretest grade is 25.4 , the average posttest score is 70.2 and the mean value of $\mathrm{N}$-gain is 0.6 which means effective. Learning using visual aids makes students more passionate, motivated, and more clear. The props in the science learning process plays an important role as a tool for creating effective science learning process [18]. To support the implementation of a fun learning process needs to be provided with sufficient props. An increase in posttest average value and an effective $\mathrm{N}$-gain value.

Based on the results of research can be said that inquiry tools argument effective to improve student learning outcomes. This is supported by the results of SPSS analysis, obtained the value of significance ( $\mathrm{sig}$ value $<0.05$ ). At the time of learning activities conducted through experiments, students are required to be actively involved in activities to prove the hypothesis that has been 
prepared. This happens because at the time of learning activities in every step of guided inquiry, students are required to provide arguments, when students are actively involved in experimental activities, it will have an effect on the pattern of student actions that are always based on the things that are scientific in this case is a skill argue. This is consistent with the assertion [19] that the learning activities conditioned through experiments in the laboratory resulted in more active learning that "forced" the students to present and claim the debate. According to [20] that laboratory-based inquiry has a significant effect on students 'learning outcomes and students' scientific attitudes. Meanwhile, according to [21] that guided inquiry has a significant impact in providing science experience, fostering students 'confidence in participating so as to improve students' skills.

Based on the results of the analysis of students' answers in giving arguments to the 8 questions after using props. The skill of making claims is obtained by increasing percentage of $47.50 \%$, or obtaining an average gain value of 0.7 which means that the argumentation inquiry tool is effective enough to improve the claim making skill. Problem number 1, the student must determine the amount of hydrostatic pressure experienced by the same object but in three different positions inside a container. Warranty skills are gained by a percentage increase of $67.75 \%$, or gain an average gain value of 0.8 which means that inquiry tools are effective arguments for improving warrant skills. Problem number 3, the student must determine the amount of pressure experienced by objects in the same depth, but the shape of the container is different. The skill of providing backing is $25.59 \%$ increase in percentage, or gain an average gain value of 0.3 which means that argumentation inquiry tools are effective enough to improve the students' skills of providing backing. The skill of giving rebuttal gained a $22.01 \%$ percentage increase, additionally, or gained an average gain value of 0.2 which means that argumentation inquiry tools are less effective at improving the students' skill in delivering rebuttal. Problem number 8 , students predict the state of an object if it is inserted into a known liquid of its type, and gives the possibility of the state of another object. The difficulty of developing the students 'argumentation skill in giving a rebuttal is due to the lack of students' knowledge of the depth of the material being mastered, the lack of other supporting sources of material understanding, so that the statements are not able to provide an alternative statement. This is supported by the assertion [22] that argumentation ability is less developed when developing more than one rebuttal with data, warrant, or backing.

Improved argumentation skills obtained an average $\mathrm{N}$-gain score of 0.5 which means that argumentation inquiry tools are effective enough to improve students' argumentation skills. This shows that students' argumentation skills have improved after carrying out learning activities using guided inquiry-based props to improve argumentation skills. Means, after the learning is done through the stages of guided inquiry, students' argumentation skills have increased. This is in accordance with the statement [8] that learning through inquiry methods is an effective teaching strategy for teaching and developing the ability to broaden argumentation skills. Meanwhile, according to [19] conditioned learning using inquiry will be able to achieve a stronger focus on student argumentation.

Increased argumentation skills will continue to increase along with the process of learning activities by applying guided inquiry strategies, using argumentation inquiry tools, or in other words increasing argumentation can be increased gradually. This is supported by statements [17] and [22] that argumentation skills will increase along with learning processes that apply 
appropriate, and gradual learning strategies. The data analysis results show a description of the answers of 75 students from 8 questions. The greatest increase in skill indicators makes warrant, ie the skill of argument based on theory or principle of $67.75 \%$. For example, in question 3 , the students presented three different container forms containing the same liquid, the students were asked to determine the amount of hydrostatic pressure experienced by the object at the same depth as the different container forms. Students are categorized in warrant if the student is able to determine the hydrostatic pressure in each container with the support of data on the problem, and the theory underlying it.

Furthermore, the smallest percentage value in the rebuttal category is $22.01 \%$. Students still find it difficult to provide alternative answers other than the options available. For example, the question no.8 students presented the mass and volume of objects, as well as the density of different types of liquids, students will determine the condition of the object if inserted into the liquid. In general, students are only able to give one answer only, the students have not been able to provide an alternative state of other objects, if the object is entered into a different type of liquid. The low skills of students in providing rebuttal statement many factors that affect them (1) source library. This is in accordance with the assertion [17] that students have difficulty in making arguments, because students are poorly trained to utilize relevant literature sources, and are not yet accustomed to making an argument. (2) Lack of student experience in implementing learning activities involving students' argumentation skills. This is in accordance with the statement [23] that to express a simple argument consisting of only one statement of course the learners have difficulty, it indicates that the learners are less experienced in developing skills to argue on their learning.

In general, there has been an increase in argumentation skills with fairly effective categories, aligned with that obtained increased learning outcomes with high or effective category. This indicates that when an increase in argumentation skills, the student learning outcomes will increase. It has the support of [20] that any increase in scientific attitudes, it will have an effect on the improvement of student learning outcomes. In addition, it has the support of [24] that there is a strong and significant relationship between arguing skills and students' cognitive abilities.

\section{Conclusions and Recommendations}

Based on the results of research and discussion it can be concluded as follows, 1) Produced two props $U$ pipe that serves to (a) determine the presence of hydrostatic pressure on the fluid and equipped with a level reader sensor, (b) prove and test Pascal's legal application, both props are made of simple materials, easy to use, and not endanger students. The tools are equipped with student worksheets following the guided inquiry stages of presenting phenomena, formulating problems, formulating hypotheses, conducting experiments, drawing conclusions, and presenting the results of experiments. 2) The static fluid props are very interesting, practical, and very useful according to the students based on field test, the attractiveness test has four aspects assessed, for the aspect of attractiveness earn $83 \%$ which means very high. Practicality test has five aspects assessed, for the aspect of attractiveness to get a value of $90 \%$ which means very high. The benefit test has six aspects that are assessed, for the aspect of attractiveness to get a value of $89 \%$ which means very high. 3) The static fluid propellant was declared effective to cultivate students' argumentation skills based on the average N-Gain score of three schools that is 0.6 which means effective. 


\section{References}

[1] Hamalik, Oemar. (2003). Proses BelajarMengajar. Bandung: Sinar Baru Algensindo.

[2] Sidharta, A. \&Yamin, W. (2013). Pengembangan Alat Peraga Sederhana Praktik (APP) IPA Sederhana Untuk Guru SMP. Bandung: P4TK IPA.

[3] Prasetyarini, A., Fatmaryanti, S.D. dan Akhdinir-wanto, R.W. (2013). Pemanfaatan Alat Peraga Sederhana IPA Untuk Peningkatan Pemahaman Konsep Fisika Pada Siswa SMP Negeri 1 Bulus pesantren Kebumen Tahun Pelajaran 2012/2013. Radiasi 2 (1): 7-10.

[4] Tiarto, E. H., \& Abdurrahman. (2015). Design of Mr.Fluid Instructional Media for Fostering Students' Creative Thinking. Proceeding International Seminar on Mathematics, Science, and Computer Science Education: Improving Quality of Mathematics, Science and Computer Science Education Through Research. Bandung: FPMIPA UPI.

[5] Pandey, G. K. Nanda, \&Ranjan, V. (2011). Effectiveness of inquiry training model over conventional teaching method on academic achievement of science student in India. Journal of Innovative Research inEducation.1(1),7-20.

[6] Nur, Muhammad. (2011). Modul Keterampilan Proses Sains. Surabaya: Pusat Matematika dan Sains Sekolah (PSMS) Universitas Negeri Surabaya.

[7] Sayekti, Ika Candra. (2012). Pembelajaran IPA Menggunakan Pendekatan Inkuiri Terbimbing Melalui Metode Eksperimen dan Demonstrasi Ditinjau Dari Kemampuan Analisis dan Sikap Ilmiah Siswa, 1(2), 142-153.

[8] Katchevich, D. Hofstein, A., \& Naaman,R. (2013). Argumentation in the Chemistry Laboratory: Inquiry and Confirmatory Experiments. Research Sains Education. 43 (1), 317 - 345.

[9] Praptiwi, L. Sarwi., \& Handayani, L. (2012). Efektivitas Model Pembelajaran Eksperimen Inkuiri Terbimbing Berbantuan My Own Dictionary Untuk Meningkatkan Penguasaan Konsep Dan Unjuk Kerja Siswa SMP RSBI. Unnes Science Educational Journal, 1(2), 87-95.

[10] Ibrahim, M. (2012). Pengembangan perangkat pembelajaran. Surabaya: Departemen Pendidikan Nasional.

[11] Arikunto, S. (2013). Dasar-dasar Evaluasi Pendidikan. Jakarta: Bumi Aksara.

[12] Mudrikah, A. (2016). Problem-Based Learning Associated by Action-Process-Object-Schema (APOS) Theory to Enhance Students' High Order Mathematical Thinking Ability. International Journal of Research in Education and Science (IJRES), 2 (1), 125-135.

[13] Chen, C. H., \& She, H. C. (2012). The Impact of Recurrent On-line Synchronous Scientific Argumentation on Students' Argumentation and Conceptual Change. Educational Technology \& Society, 5(1), 197 - 210.

[14] Widiyatmoko, A., \& Pamelasari, S. D. (2012). Pembelajaran Berbasis Proyek untuk Mengembangkan Alat Peraga IPA dengan Memanfaatkan Baahan Bekas Pakai. Jurnal Pendidikan IPA Indonesia, 1 (1), 51-56.

[15] Arsito, R. (2004). Media Pembelajaran.Jakarta: Depdiknas.

[16] Wenning, C. J. (2011). Experimental Inquiry in Introductory Physics Courses. Journal of Physics Teacher Education. 6 (2), 9-16

[17] Ch, Ida Farida., \& Gusniarti, W. F. (2014). Profil Ketrampilan Argumentasi Siswa Pada Kosep Koloid yang Dikembangkan Melalui Pembelajaran Inkuiri Argumentasi. Edusains, 6(1), 32-40.

[18] Sudjana, N. (2002). Dasar-dasar Proses Belajar Mengajar, Bandung: Sinar Baru.

[19] Kind, P. M., Kind, V., Hofstein, A., \& Wilson, J. (2012). Peer Argumentation in the School Science Laboratory-Exploring Effect of Task Features. International Journal of Science Education, 33 (18), 1-31.

[20] Maretasari, E., Subali, B., \& Hartono. (2012). Penerapan Model Pembelajaran Inkuiri Terbimbing Berbasis Laboratorium untuk Meningkatkan Hasil Belajar dan Sikap Ilmiah Siswa. Unnes Physics Education Journal, 1 (2), 27-31. 
[21] Martineau, C., Traphagen, S., \& Spakes, T. (2013). A Guided Inquiry Methodology to Achieve Authentic Science in a Large Undergraduated Biology Course. Journal of Biological Education, 47 (4), 240-245.

[22] Hasnunidah, N., \& Susilo, H. (2015). Profil Perspektif Sosiokultural Mahasiswa dalam Berargumentasi Pada Mata Kuliah Biologi Dasar. Seminar Nasional XI Pendidikan Biologi FKIP UNS, 14-124.

[23] Viyanti, Cari, C., Sunarno, W., \& Prasetyo, Z. K. (2017). Level of Skill Argued Students on Physics Material. Journal of Physic, 895(1), 1-6.

[24] Siswanto, Kaniawati,I. \& Suhandi, A. (2014). Penenrapan Model Pembelajaran Pembangkit Argumen Menggunakan Metode Saintifik untuk Menigkatkan Kemampuan Kognitif dan Keterampilan Berargumentasi Siswa. Jurnal Pendidikan Fisika Indonesia, 3 (1), 104-116.

*Corresponding author.

E-mail address: asuyatna@yahoo.com 